\title{
The Effect of Automated Underwriting on the Profitability of Mortgage Securitization ${ }^{1}$
}

\author{
Wayne Passmore \\ (Corresponding Author) \\ Senior Economist \\ Federal Reserve Board \\ Mail Stop 89 \\ Washington D.C. 20551 \\ Phone: 202-452-6432 \\ Fax: 202-452-3819 \\ M1SWP00@FRB.GOV \\ and \\ Roger Sparks \\ Associate Professor \\ Economics Dept. \\ Mills College \\ Oakland, CA 94613
}

\footnotetext{
${ }^{1}$ The views expressed here are solely those of the authors, and do not represent the views of the Board of Governors, other staff at the Board of Governors nor anyone else associated with the Federal Reserve System. We wish to thank Glenn Canner, Frank Nothaft, and Steve Oliner for their thoughtful comments, and Mark Fisher for his Mathematica expertise.
} 


\title{
The Effect of Automated Underwriting on the Profitability of Mortgage Securitization
}

\begin{abstract}
Over the past two years, many mortgage market analysts have praised automated underwriting as a technological innovation that will lower the costs of processing mortgage applications. However, automated underwriting is unlikely to decrease processing costs uniformly for all mortgage applications. Instead, it makes identifying and processing low-risk mortgage borrowers less costly, but may not significantly lower the costs of identifying and processing relatively high-risk applicants. Our results suggest that after the one-time cost reduction produced by automated underwriting, the resulting mortgage market equilibrium is characterized by lower mortgage rates and lower profits for the mortgage securitizer.
\end{abstract}




\section{The Effect of Automated Underwriting on the Profitability of Mortgage Securitization}

\section{Introduction}

Over the past two years, many mortgage market analysts have praised automated underwriting as a technological innovation that will lower the costs of processing mortgage applications. However, automated underwriting is unlikely to decrease processing costs uniformly for all mortgage applications. Instead, it makes identifying and processing low-risk mortgage borrowers less costly, but may not significantly lower the costs of identifying and processing relatively high-risk applicants. Ironically, by only lowering the costs of determining who is a lower-risk applicant, automated underwriting--the technological innovation in the mortgage markets during the 1990s--may undermine the profitability of the most important mortgage market innovation during the 1980s--mortgage securitization.

Mortgage originators who can fund mortgages directly (e.g. banks and thrifts) can potentially engage in adverse selection against the mortgage securitizer, holding relatively more good credit risks in portfolio and selling poorer credit risks. ${ }^{2}$ In this setting, originators who acquire a lower-cost method of underwriting mortgage applicants may screen and hold more of the less risky mortgages. The securitizer reacts to greater adverse selection by raising yields on mortgage-backed securities, which reduces the originators incentive to screen. Our restuls suggests that after the one-time cost reduction produced by automated underwriting, the resulting equilibrium is characterized by lower mortgage rates and lower profits for the mortgage securitizer.

\section{Automated Underwriting and the Mortgage Market}

Automated underwriting has three components: a credit assessment using a credit

\footnotetext{
${ }^{2}$ We use the term mortgage securitization, but our model applies to any process where someone other than the mortgage originator bears the credit risk of the mortgage (for example, mortgage insurers, or mortgage purchasers who then hold the mortgage in their own portfolio.)
} 
score, an evaluation of the borrower's ability to carry debt using financial ratios, and a collateral assessment using a statistical appraisal of property. One or all of these components can be automated, although the focus of most automation efforts is to combine a easy-toobtain consumer credit score with a minimal amount of other information to produce a mortgage credit score for the applicant.

Credit scoring is a means of evaluating the creditworthiness of loan applicants using a numerical index. ${ }^{3}$ If the index exceeds a predetermined threshold, then the applicant is extended credit subject to verification of information; otherwise, the applicant is either referred to a human underwriter for additional review or is denied credit.

Used for years in the credit card industry, credit scoring has only recently been applied to mortgage applications by depository institutions, mortgage insurance companies, and mortgage securitizers. These firms argue that combining the consumer credit scoring with other financial information can produce mortgage credit score that is a reliable measure of credit risk. According to these firms, basing mortgage credit decisions on a mortgage credit score will lower the cost of origination and speed up the approval process because the score can be generated quickly from data available at the time of application.

To produce a mortgage credit score quickly, most automated mortgage underwriting systems rely heavily on the consumer credit reports produced by three major consumer credit bureaus in the United States: Equifax, Trans Union and Esperian (formerly TRW). Information from the bureaus can be electronically retrieved within minutes and then integrated into a mortgage credit scoring model. ${ }^{4}$

${ }^{3}$ For a detailed overview of credit scoring in the mortgage market, see Robert A. Avery, et.al. (1996). For more general reviews of credit scoring, see Altman(1980), Altman and Haldman (1995), Greene (1992), and Lewis (1994).

${ }^{4}$ Most credit scoring algorithms for mortgages retrieve only a summary credit score from the credit bureau (in the United States, this summary score is almost always created for the credit bureau by either Fair, Isaac Companies or by Management Decision Systems). The summary scores, along with other information, are then incorporated into a mortgage credit scoring algorithm. Fannie Mae's and Freddie Mac's guidelines suggest that the creditor use at least two credit bureau scores. 
But in an automated underwriting system for mortgages, the consumer credit report is not the sole determinant of creditworthiness. Other important determinants are the value of the property relative to the loan being requested and the payment burdens imposed by the mortgage, information that may not be available at the time of application. In addition, the applicant may provide information about their income, wealth, and employment on the mortgage application, but this information can be difficult to verify quickly. The absence of accurate, validated information makes the assessment of creditworthiness less precise, and mortgage originators often respond by setting a relatively high credit score threshold for immediate loan approval. ${ }^{5}$

The two government-sponsored enterprises that dominate the conventional mortgage markets, the Federal National Mortgage Association (Fannie Mae) and the Federal Home Loan Corporation (Freddie Mac) are strong proponents of credit scoring and automated underwriting. Freddie Mac's credit scoring system, Loan Prospector, is one of the most advanced mortgage credit scoring systems. This system predicts the applicant's default risk based on his or her credit file and on loan application information. ${ }^{6}$ The lender either requests an automated statistical appraisal from Freddie Mac or provides an appraisal. Based on the default prediction, Freddie Mac either agrees to purchase the mortgage or refers it to traditional underwriting. Using this system, 50 to 60 percent of mortgages can be processed

${ }^{5}$ Along with problems associated with data availability and accuracy, the relative inexperience with credit scoring for mortgages raises questions about its reliability. Overriding these concerns, however, is the intense competition in the mortgage industry, which is hastening the rapid adoption of these techniques.

${ }^{6}$ Loan Prospector's scoring system is proprietary. However, based on information published by Freddie Mac and Fannie Mae, as well as the score card used in Freddie Mac's Affordable Housing program (called the "Gold Measure Worksheet"), the bulk of the judgement about future delinquency or default is based on the credit score created from the credit bureau file (see Holloway and Jaske (1995)), while traditional underwriting measures (loan-to-value ratios and debt burden ratios) receive significantly less weight. Many of the determinants of mortgage default, such as loan-to-value ratios, are well-established. However, there is still substantial variation in defaults risks (see Vandell (1993, 1995), Quigley and Van Order(1995), and Guttentag (1992).) 
in under 10 days, with a cost savings of about $\$ 1000$ per loan. As both GSEs are trying to establish market share (many lenders may not use both systems), charges for Loan Prospector have been minimal. ${ }^{7}$ By October 1996, 350 lenders were actively using Loan Prospector with about 13,000 mortgages scored each month--about 20 percent of Freddie Mac's purchase volume. Freddie Mac expects about 50 percent of its loans to be scored by the end of $1997 .{ }^{8}$ Many observers expect that soon all mortgage applications will be initially evaluated according to the applicant's credit score. ${ }^{9}$ The gains to credit scoring, however, will not accrue to all applicants equally. As expressed by one provider of mortgage credit:

Only when information is clear-cut, as it is with applicants from both extremes of the creditworthiness spectrum, is the fully automated system at its peak reliability. Lenders need only look at a "in-file" credit report to grant a loan to a good credit applicant--or to deny a loan to an applicant with poor credit. In the large gray area between, good underwriting expertise is key because an automated data base cannot determine whether a gray-area loan should be approved. In these cases, human judgement and discretion are needed (Kunkel, 1995).

If this statement is accurate, then the bulk of the cost savings from automated underwriting accrues during the evaluation of applicants who have either very good or very bad credit records. In such cases, a credit report alone is most often sufficient for the lender to decide whether or not to extend credit. Other mortgages are referred to human underwriters, with little obvious cost savings for these applicants.

${ }^{7}$ For a detailed review of the systems offered by Freddie Mac and Fannie Mae, see the annual report of their regulator, the Office of Federal Housing Enterprise Oversight (OFHEO, 1995 and 1996).

${ }^{8}$ See "Freddie: Automated System to Bring Half of 1997 Volume," American Banker, November 18, 1996. Fannie Mae is also strongly pushing credit scoring with a system that is similar to Loan Prospector (see "Fannie Makes A Commitment to Credit Scoring," American Banker, November 1, 1995.)

${ }^{9}$ Freddie Mac is now working with the Federal Housing Administration (the FHA) on the scoring of government-insured mortgages and has extended its models to nonconforming mortgages such as jumbo loans. 


\section{Mortgage Securitization, Adverse Selection and Automated Underwriting}

Mortgage securitization affects the origination and funding of mortgages in two important ways. First, it lowers the cost of offering mortgages when the securitizer of the mortgage can bear the credit risk associated with the mortgage at a lower cost than the originator (for example, the securitizer may have government-sponsored status).

Second, mortgage securitization introduces an information asymmetry into the mortgage origination process. When the option to securitize is available, if a mortgage originator suspects that a mortgage applicant is a bad credit risk, the originator may keep this information hidden and attempt to sell the mortgage to a securitizer rather than deny credit to the mortgage applicant. The originator's action of selling mortgages of poor credit quality is an example of adverse selection, which lowers the securitizer's profits and can possibly offset the cost advantages of securitization. ${ }^{10}$

Adverse selection is a persistent problem for mortgage securitizers. To quote the Chairman of Fannie Mae, speaking to mortgage bankers:

We can't and we won't work with you just on the "hard" cases, the special cases and the riskier cases. The profile of the loans you deliver to us must be similar to the profile of all the conventional mortgages you are originating. If the risk profile of the business you deliver to us differs substantially from the risk profile of your overall book of business, then we will have no choice but to believe we have been "adversely selected. ${ }^{11}$

In the conventional mortgage market--that is, mortgages without FHA or VA backing, Fannie Mae and Freddie Mac dominate the securitization of conforming mortgages, that is mortgages that meet the underwriting guidelines of Fannie Mae and Freddie Mac and fall under the size limit (currently $\$ 214,600$ ) imposed by Congress. ${ }^{12}$ Fannie Mae and Freddie

${ }^{10}$ For a discussion about the conditions under which adverse selection with mortgage securitization can raise, rather than lower, mortgage rates, see Passmore and Sparks (1996).

${ }^{11}$ Jim Johnson, Chairman, Fannie Mae, quoted in "Comment: Wholesale Lending Leaves Mortgage Out of the Loop," American Banker, October 31, 1995.

${ }^{12}$ For a discussion of their dominance, see Chinloy (1995), Goodman and Passmore (1992), and Hermalin and Jaffee (1996). 
Mac generally offer one price for conforming mortgages (adjusting for the terms of the mortgages), because from their perspective these loans are of uniform credit quality. ${ }^{13}$

If the originator has better information than the mortgage securitizer does about the credit quality of the mortgage, then the potential for adverse selection exists. Credit scoring makes it easier for the securitizer to signal to the originator whether a potential mortgage will be purchased by the securitizer. But it also changes the technology of the originator by allowing the originator to build or purchase its own inexpensive credit scoring models.

The model we outline below applies to conforming mortgages that have already passed the mortgage credit score thresholds established by purchasers such as Fannie Mae and Freddie Mac. In this model, the originator has its own credit scoring technology that uses information not captured by the underwriting guidelines defined by the mortgage purchaser. The originator compares its score to that of the mortgage purchaser, and decides whether or not to sell the mortgage. ${ }^{14}$

As we formally demonstrate with our model, if automated underwriting lowers the cost to the originator of identifying good credit risks, then the potential grows for adverse selection against a mortgage securitizer. As credit histories become less costly to identify and score, mortgage originators find it easier to determine who the mortgage securitizer views

13 The very limited nature of risk-adjusted pricing by Fannie Mae and Freddie Mac is described by trade press articles, such as by Staples (1996), even though housing markets are not completely homogenous (see Abraham, et. al., 1994). Of course, the mortgage terms (rates, terms, points, rate adjustments and the like) can vary across conforming mortgages. In particular, private mortgage insurance is often required for some mortgages to make them conforming. The cost of this insurance to the borrower is, to some extent, a risk-adjustment to the price of the mortgage. But once private mortgage insurance is purchased, the price offered for purchasing the insured mortgage is unchanged.

${ }^{14}$ While there are over 10,000 mortgage originators, the market is somewhat concentrated. Four originators account for over one-quarter of the mortgages sold to Fannie Mae, Freddie Mac and Ginnie Mae (Norwest Mortgage, Countrywide Home Loans, Chase Manhattan Mortgage and Fleet Mortgage Corp.). These institutions have ample resources for developing and maintaining their own credit scoring models. Countrywide's credit scoring model includes a measure of the likelihood that Fannie Mae or Freddie Mac will purchase the loan. 
as a good risk and yet still have their private information based on "their local knowledge, direct contact with borrowers and expert judgement." 15 This will make it less costly for originators to "game" the mortgage securitization process, which lowers the profits of the mortgage securitizer. ${ }^{16}$

Our model also highlights the benefit of automated underwriting to the mortgage borrower. Since origination costs are reduced, the mortgage rate falls for all conforming mortgages. There may be other benefits of automated underwriting, such as making the mortgage decision more objective and allowing a wider range of factors to be considered, which are not addressed by our model. ${ }^{17}$

Proponents of automated underwriting are hopeful that it can also alleviate concerns about possible discrimination against nontraditional mortgage applicants (discrimination based on gender, race or ethnic group) because its treatment of mortgage applicants is independent of the likes and dislikes of a particular mortgage originator. As our model is limited to the discussion of conforming mortgage borrowers (and thus all applicants become borrowers), it has few implications for the acceptance or rejection of nonconforming-mortgage applicants. However, to the degree that nontraditional borrowers or borrowers with small downpayments are currently more costly to screen, our model suggests that credit scoring will result in more of these mortgages being held in bank portfolios rather than being securitized because mortgage credit scoring will make it less costly for the bank to determine the applicant's

${ }^{15}$ This description of the value added by mortgage originators in given by Mr. Johnson in his speech to mortgage bankers, op. cit.

16 In our model, the originator cannot offer different mortgage rates to different risk types. We assume that the mortgage rate is posted prior to screening, and that changing the offered mortgage rate after screening would be a difficult business practice. In addition, all mortgages in our model are mortgages that meet the securitizer's underwriting standards. Thus, to deny someone the posted mortgage rate would require a denial that is not based on public credit history, loan characteristics or well-known borrower characteristics but instead based on the originator's private information about the borrower or the community.

${ }^{17}$ See Freddie Mac (1996) for a strong statement promoting the advantages of credit scoring, as well as Fannie Mae's letter to its sellers (1997). 
credit quality. ${ }^{18}$ Ironically, Fannie Mae and Freddie Mac, who are both strong proponents of automated underwriting and who are both under pressure to increase their purchases of mortgages extended to lower-income borrowers, may find it more difficult to increase the holdings of these types of mortgages as automated underwriting becomes more prevalent. ${ }^{19}$

\section{The Model}

To examine the issues described above, we employ a model of the interactions between mortgage borrowers, mortgage originators (here referred to as "banks"), and the mortgage securitizer. The model has two types of mortgage borrowers who qualify for securitization. Type A households have a low probability of defaulting on a mortgage, whereas type B households have a high probability of defaulting. The probabilities of default are denoted by $q_{B}>q_{A}>0$ respectively. All agents know that the proportion of type $A$ households is $\mathrm{p}$ and that the proportion of type B households is (1-p). Initially, however, nobody knows the type of any individual applicant; the bank only obtains this information through screening an applicant.

To introduce the idea of disparate screening (underwriting) costs, we assume that there are infinitely many type A customers whose expected screening costs, $\alpha \mathrm{c}_{\mathrm{i}} \mathrm{i}=1, \ldots, \infty$, are distributed uniformly on the real line interval $[0, \alpha]$, where $c_{i} \in[0,1]$. Likewise, type $B$ customers have expected screening costs, $\beta \mathrm{c}_{\mathrm{i}} \mathrm{i}=1, \ldots, \infty$, which are distributed uniformly on the real line interval $[0, \beta]$, where $c_{i} \in[0,1]$ and $\beta>\alpha$. These assumptions imply that type $B$ borrowers have, on average, higher screening costs that type A borrowers, and that at lower levels of screening costs there are more type A borrowers than type B borrowers.

\footnotetext{
${ }^{18}$ The higher risks low downpayment borrowers is discussed in Deng, et. al. (1996). However, credit scoring, to the degree it allows underwriters to rely less on downpayment to control default risk, also may substanitally increase the number of lower-income borrowers coming into the market (see Linneman and Wachter, 1989).

${ }^{19}$ Both Fannie Mae and Freddie Mac must meet goals, established by HUD, about the proportion of low income, central city and affordable housing mortgages purchases among their annual purchases of mortgages. For a brief review of these goals, see the OFHEO annual report (1995), pages 12-14.
} 
We capture the notion that mortgages yield a higher expected return when they are extended to low-risk borrowers rather than to high-risk borrowers by defining:

$$
\begin{aligned}
& r_{A} \equiv\left(1-q_{A}\right) r+q_{A} r_{D A} \\
& r_{B} \equiv\left(1-q_{B}\right) r+q_{B}{ }^{r} D B
\end{aligned}
$$

where $r_{j}(j=A, B)$ is the gross expected rate of return on a mortgage extended to a type $j$ borrower, $q_{j}$ is the default probability, $r$ is the posted mortgage rate, and $r_{D j}$ is the return on a defaulted mortgage. Assuming that $\mathrm{q}_{\mathrm{A}}<\mathrm{q}_{\mathrm{B}}$ and that $\mathrm{r}>\mathrm{r}_{\mathrm{DA}}>\mathrm{r}_{\mathrm{DB}}$, we obtain the desired result that the expected return on a type A mortgage is greater than the expected return on a type B mortgage (i.e. $\mathrm{r}_{\mathrm{A}}>\mathrm{r}_{\mathrm{B}}$ ).

To focus attention on equilibria where at least some mortgages are securitized, we assume that $r_{A}>r_{S}+\delta>r_{B}$, where $r_{S}$ is the yield on the mortgage-backed security and $\delta>0$ is the private value of liquidity to the lender who holds a mortgage-backed security rather than a mortgage itself. Thus, $\mathrm{r}_{\mathrm{S}}+\delta$ is the total return to the lender from securitizing the mortgage.

The inequality $r_{S}+\delta>r_{B}$ implies that it is more profitable for the loan originator to securitize the mortgages of know type Bs, where this knowledge is acquired either by screening the applicant or by observing that the applicant's screening cost is too high to be consistent with a type A. (Since type B's have, on average, higher screening costs than type A's, some type B's are readily identified by their high screening costs $\left(\beta c_{i}>\alpha\right)$, and do not require screening to reveal their type.) Conversely, the inequality $r_{A}>r_{S}+\delta$ implies that the originator will not securitize the mortgages of screened type As.

The originator must also decide what to do with unscreened mortgages of unknown types. Two cases are of interest:

$$
\begin{array}{ll}
\text { Case 1: } & r_{s}+\delta>z \\
\text { Case 2: } & r_{s}+\delta \leq z
\end{array}
$$

where $z$ (which equals $\mathrm{p}_{\mathrm{A}}+(1-\mathrm{p}) \alpha / \beta \mathrm{r}_{\mathrm{B}}$ ) is the return on a portfolio of unscreened 
mortgages held by the banks.

In Case 1, the return from securitizing exceeds the expected return from holding an unscreened mortgage, so the originator chooses to securitize all unscreened mortgages as well as the screened type Bs. Only the mortgages of screened type As are held in the bank's portfolio. In Case 2, the originator securitizes only mortgages of known type Bs and holds all other mortgages in its portfolio.

\section{Who Gets Screened?}

We assume that the originator knows the cost of screening (underwriting) each mortgage applicant. To maximize profits, the originator chooses a "cutoff" screening cost (here denoted k). All applicants above this cost $\mathrm{k}$ are not screened and all below are screened. The cutoff is always chosen such that $\mathrm{k} \leq \alpha$ because all applicants with costs above $\alpha$ are already know to be type Bs, and screening them provides no additional information. From our assumptions on the distributions of screening costs, we may write the conditional probability that a screened applicant is a type A as:

$$
P_{A}=\frac{p \beta}{p \beta+(1-p) \alpha}
$$

and the probability that a screened applicant is a type $\mathrm{B}$ is $1-\mathrm{P}_{\mathrm{A}}$.

Let $s_{i}$ denote applicant I's screening cost, which the originator observes costlessly. In Case 1 , the originator compares the returns from not screening to the returns from screening and decides not to screen if and only if:

$$
r_{S}+\delta>P_{A} r_{A}+\left(1-P_{A}\right)\left(r_{S}+\delta\right)-S_{i}
$$

which says that the return from not screening and then securitizing the mortgage exceeds the expected return from screening the mortgage. 
The cutoff screening cost for Case $1, \mathrm{k}_{1}$, is computed by solving for $\mathrm{s}_{\mathrm{i}}$ with (4) rewritten as an equality and imposing the constraint $\mathrm{k}_{1} \leq \alpha$ :

$$
k_{1}=\min \left[P_{A}\left(r_{A}-r_{S}-\delta\right), \alpha\right]
$$

Since applicants with screening costs at or below $\mathrm{k}_{1}$ are screened, equation (5) suggests that the originator desires to screen more applicants as the return on a type A mortgage increases relative to the return on a mortgage backed security (but in equilibrium the securitizer might raise the MBS rate to offset this desire). We also note that screening increases with (i) an increase in the the probability of a screened applicant being a type A, (ii) a fall in the cost of screening a type $A$ falls relative to a type $B$ (note that $\alpha / \beta$ is part of $\mathrm{P}_{\mathrm{A}}$ ), and (iii) a rise in the proportion of type $\mathrm{A}$ 's in the population, $\mathrm{p}$.

Similarly, we solve for the cutoff screening cost in Case 2, where unscreened borrowers are held in the bank's portfolio rather than securitized. In this case, the originator will not screen if:

$$
P_{A} r_{A}+\left(1-P_{A}\right) r_{B}>P_{A} r_{A}+\left(1-P_{A}\right)\left(r_{S}+\delta\right)-s_{i}
$$

Solving for the cutoff in Case 2 yields:

$$
k_{2}=\min \left[\left(1-P_{A}\right)\left(r_{S}-\delta-r_{B}\right), \alpha\right]
$$

The dependence of $\mathrm{k}_{1}$ and $\mathrm{k}_{2}$ on $\mathrm{r}_{\mathrm{S}}$ provides a means by which the mortgage securitizer may, by setting $\mathrm{r}_{\mathrm{s}}$, influence the proportion of borrowers screened, and whether the originator securitizes unscreened mortgages (that is, whether Case 1 or Case 2 holds). We now turn to solving for $\mathrm{r}_{\mathrm{S}}$. 


\section{Solving for the MBS Interest Rate}

In our model, the bank decides which mortgage applicants to screen using the marginal profit conditions described above, while taking as given both the interest rate on mortgages and the yield on mortgage-backed securities (MBS). In Case 1, the bank screens all applicants with screening costs at or below level $\mathrm{k}_{1}$, whereas in Case 2, the cutoff is $\mathrm{k}_{2}$. Now we consider the possibilty of strategic behavior by the mortgage securitizer. Suppose the securitizer knows the bank's screening rule and acts like a Stackleberg monopolist, adjusting the MBS rate to reflect this knowledge. The securitizer influences the bank's screening in two ways: by putting the bank in Case 1 or Case 2, as indicated in (2), and by determining the bank's cutoff screening cost within each case. The mortgage securitizer desires to limit the amount of screening because screening leads to adverse selection, as the bank keeps all type As who are found.

We assume that the mortgage rate is determined by the competitive nature of the mortgage origination industry, where the easy entry and exit of mortgage originators drives economic profits to zero. Thus, an equilibrium set of mortgage and MBS rates is one where the securitizer's profits are maximized, each bank follows the optimal screening rule, and the bank's profit are zero. We now describe how we derive this equilibrium.

In Case 1, the mortgage securitizer's expected return per mortgage applicant (above the securitizer's cost of capital, $\mathrm{r}_{\mathrm{k}}$ ) are:

$$
\Pi_{S I}=\lambda_{u} *\left[z-r_{S}-\frac{r_{k}}{L}\right]+\lambda_{S} *\left(1-P_{A}\right)\left[r_{B}-r_{S}-\frac{r_{k}}{L}\right]+\lambda_{B} *\left[r_{B}-r_{S}-\frac{r_{k}}{L}\right]
$$

where $\mathrm{L}$ is the securitizer's leverage, $\lambda_{\mathrm{u}}$ is the proportion of mortgages that are unscreened and have screening costs in the range $s_{i} \leq \alpha$, too low to imply the applicant is necessarily a type $\mathrm{B} ; \lambda_{\mathrm{s}}$ is the proportion of mortgages that are screened; and $\lambda_{\mathrm{B}}$ is the proportion of mortgage that are unscreened and have screening costs $s_{i}>\alpha$, signaling to the originator that the applicant is a type B. On unscreened mortgages, the securitizer earns $\mathrm{z}$--the return on an unscreened portfolio (which is $\mathrm{P}_{\mathrm{A}}{ }^{*} \mathrm{r}_{\mathrm{A}}+\left(1-\mathrm{P}_{\mathrm{A}}\right) * \mathrm{r}_{\mathrm{B}}$--and incurs costs of $\mathrm{r}_{\mathrm{S}}+\mathrm{r}_{\mathrm{K}} / \mathrm{L}$. For screened mortgages and for mortgages that are clearly type Bs because of high screening costs, the 
securitizer earns $r_{B}$ and again incurs costs of $r_{s}+r_{k} / L$.

In Case 2, the mortgage securitizer's expected return is:

$$
\Pi_{S 2}=\lambda_{u} *\left(1-P_{A}\right)\left[r_{B}-r_{S}-\frac{r_{k}}{L}\right]+\lambda_{B} *\left[r_{B}-r_{S}-\frac{r_{k}}{L}\right]
$$

In this case, the securitizer can purchase only type Bs, which yield a positive profit if $r_{B}$ is greater than $r_{s}+r_{k} / L$. On the other hand, the bank would not securitize type $B$ mortgages unless $r_{\mathrm{s}}+\delta>\mathrm{r}_{\mathrm{B}}$. Combining these two inequalities, we find that Case 2 can only be an equilibrium if $\delta>\mathrm{r}_{\mathrm{B}}-\mathrm{r}_{\mathrm{s}}$, that is, bank's private liquidity premium must be positive and rather large.

The mortgage securitizer must consider both Case 1 and Case 2 simultaneously, and will not operate if profits are negative. The mortgage securitizer maximizes profit, taking into account the bank's optimal choices of screening threshold, k. The bank's choice of cutoff screening cost determines the proportions of mortgages screened and unscreened. Thus, changes in $r_{S}$ affect both the costs and the expected revenues of the mortgage securitizer. For example. Lowering $r_{S}$ decreases the mortgage securitizer's interest payout on the MBS but increases the proportion of borrowers screened. The latter effect implies that each securitized mortgage is more likely to be a bad risk, thereby reducing the mortgage securitizer's expected revenues.

Using equations (5) and (7), and our assumptions about the distributions of screening costs, we find that the proportion of unscreened mortgages of unknown type is :

$$
\lambda_{u}=\left(1-k^{*} / \alpha\right) p+\left(\frac{\alpha}{\beta}-k^{*} / \beta\right)(1-p)
$$

and the proportion of unscreened mortgages of known type Bs is:

$$
\lambda_{B}=\frac{p k}{\alpha}+\frac{(1-p) k}{\beta} .
$$


The proportion of mortgages screened is:

$$
\lambda_{s}=\frac{p k}{\alpha}+\frac{(1-p) k}{\beta}
$$

Examining the bounds for $\mathrm{k}$, we note that if $\mathrm{k}^{*}=0$, then the bank only knows the type for borrowers whose screening costs are above $\alpha$. Whereas if $k=\alpha$, the bank knows the type of all mortgage borrowers.

We solve for the mortgage securitizer's optimal choice of the MBS rate using the program Mathematica (Wolfram, 1991). The actual solution is messy, but it can be written as:

$$
r_{s}^{*}=g\left(\alpha, \beta, r, p, q_{A}, q_{B}, r_{D}, r_{k}, L\right)
$$

The securitizer's choice of MBS rate is dependent on the mortgage rate. We solve for the mortgage rate by examining the condition that long-run bank profits are zero.

\section{Solving for the Mortgage Interest Rate}

In Case 1, the bank's expected profit function is:

$$
\Pi_{B 1}=\lambda_{u}\left(r_{S}+\delta\right)+\lambda_{s}\left[P_{A} r_{A}+\left(1-P_{A}\right)\left(r_{s}+\delta\right)\right]+\lambda_{B}\left(r_{s}+\delta\right)-C_{S}-C_{F}
$$

where $\mathrm{C}_{\mathrm{s}}$ represents screening costs and $\mathrm{C}_{\mathrm{F}}$ represents funding costs. In Case 1, the return on unscreened mortgages is the MBS rate plus the liquidity value of the securities $(\delta)$, whereas in Case 2 it is the weighted average rate of unscreened mortgages, z. All other components of the profit function are the same in the two cases. Thus, 


$$
\Pi_{B 2}=\lambda_{u} z+\lambda_{s}\left[P_{A} r_{A}+\left(1-P_{A}\right)\left(r_{s}+\delta\right)\right]+\lambda_{B}(r+\delta)-C_{S}-C_{F}
$$

The costs of screening, summed across type A's and B's, are:

$$
C_{S}=k\left[\frac{k}{2 \alpha}+\frac{k}{2 \beta}\right]
$$

If $\mathrm{k}=\alpha$, then all type A's are screened and their average cost is $\alpha / 2$. Not all type B's are screened because some have costs above $\alpha$.

Finally, the funding costs to the bank for the mortgages held in portfolio are a combination of deposits and a minimal return on capital. As will be described below, our model imposes on the banking industry a long-run condition of a competitive return on equity. For simplicity, and because our focus is not on bank liabilities, we assume that the regulatory capital standards are binding, that the bank always prefers low-cost insured deposits for funding, and that the bank's cost of funds is:

$$
C_{F}=r_{f}(1-k a p)+r_{k} k a p
$$

where $r_{f}$ is the deposit rate, $r_{k}$ is the minimum return on equity and kap is the regulatory capital requirement.

We assume that the bank posts a mortgage rate for a conforming mortgage, and has already determined that the borrower qualifies for such a mortgage. The bank cannot make the mortgage rate contingent on the private information that the bank would acquire about the borrower's credit risk if it decides to screen the borrower because it would reveal the private information to the securitizer (it would also be difficult to implement because the prescreening mortgage rate has already been advertised). In the long-run, capital inflows or outflows will drive the expected profits from mortgage applicants to equal $r_{K}$. In other words, the bank's profit, are zero.

We use Mathematica to solve the equation describing the securitizer's choice of MBS 
rate (equation 12) and an equation setting bank profits equal to zero simultaneously for $r$ and $\mathrm{r}_{\mathrm{S}}$. This set of rates, which are unique in our model, describe a long-run mortgage market equilibrium. Once $\mathrm{r}$ and $\mathrm{r}_{\mathrm{s}}$ are know, then $\mathrm{k}$ and the securitizer's profits are known. Since the proportion of mortgages screened $(\mathrm{k})$ is bounded between zero and $\alpha$, we must check any proposed parameterization of the model to see that these conditions are met.

\section{Parameterization of the Model}

In our example, we assume that 80 percent of the mortgage applicants are type $\mathrm{A}$ borrowers and 20 percent are type B. By assumption, Type A borrowers have an annual default rate of 10 basis points and type B a default rate of 60 basis points, implying that the aggregate default rate for all mortgages held by all institutions would be 56 basis points.

The cumulative default rate for Freddie Mac mortgages during the 1980s and early 1990s was about 2.16 percent, with default rate ranges from .79 to 6.20 percent depending on the loan-to-value ratio for the mortgage. This ranges imply annual default rates from under 10 basis points to as high as 60 basis points. For FHA loans, the cumulative default rates range from 5 percent to 15 percent, implying annual default rates ranging from 50 to 150 basis points. ${ }^{20}$ Thus, our assumptions for this example seem to be well within the range of plausible values.

We assume the losses on defaults are 40 percent of the loan amount for type A mortgages and 50 percent for type B mortgages. For Freddie Mac, losses on a foreclosure run about 40 percent on their typical conforming mortgage of roughly $\$ 110,000 . .^{21}$ Losses

${ }^{20}$ For Fannie Mae and Freddie Mac delinquency rates, see their 1995 Annual reports. For Freddie Mac's cumulative default rate, see R. Van Order and P. Zorn (1995). For FHA default rates, see Berkovec, et. al (1994). For an analysis which includes a comparison of this default and loss rates of these institutions see G. Canner. W. Passmore and B. Surette (1996).

${ }^{21}$ Van Order and Zorn, op. cit.

22 However, if the mortgage is cured through either a loan modification or a home sale prior to foreclosure, the losses may fall to a range of $\$ 7,000$ to $\$ 24,000$. See "Examining Secondary Market Trends, America's Community Banker, April 1996. 
on FHA mortgages range from 45 to 55 percent. Thus, our assumed loss rate is also within the reasonable range of values.

The minimum regulatory capital requirement for a bank's mortgage holdings is 4 percent, but in practice regulators encourage banks to maintain ratios above 5 percent, the rate we used in our numerical optimization. The securitizer in our model must hold the regulatory minimum capital requirement currently applied to Fannie Mae and Freddie Mac: 45 cents of capital for each $\$ 100$ of MBSs issued.

We assume that the shareholders of a bank expect a minimum return of 15 percent on their capital, a value consistent with actual bank returns on equity during the 1990s. The allin-cost, weighted-average cost of funds for the banks is set a 5 percent, a figure again chosen to be consistent with recent history.

Several studies have attempted to measure the value of securitization in the mortgage market by comparing the yield on mortgages above the conforming size limit to the yield on mortgages below the conforming size limit. This measure has many problems, but the stylized fact that arises from these investigations is that government-sponsored securitization may have lowered mortgage rates anywhere from zero to 50 basis points, with the average value hovering around 25 basis points but trending down in recent years. ${ }^{23}$ For our simulation, we assume that the value to the bank of the liquidity from holding a mortgagebacked security is 20 basis points. ${ }^{24}$

Of course, the mortgage securitizer captures some of this value when setting the MBS interest rate. It does not, however, appear that much of this liquidity premium is captured in

\footnotetext{
${ }^{23}$ See Cotterman (1994), Cotterman and Pearce (1996), Hendershott and Shilling (1989), Nothaft (1996), and Treasury (1996).

${ }^{24}$ Of course, some of this "liquidity" is an artifact of special treatment for government agency mortgage backed securities. For example, bank regulators also allow the bank to hold less capital if mortgages are held as securities issued by government-sponsored enterprise or agency. This capital inducement may have cause some depository institutions to shift to holding more mortgage-backed securities. See Cordell and King (1995) and Passmore (1994). In addition, many investment entities (e.g. municipalities, trusts, mutual funds) can only invest in government agency mortgage-backed securities.
} 
the securitization fees. For example, Fannie Mae and Freddie Mac generally charge about 24 basis points or less for a securitization, of which roughly 7 to 12 basis points is thought to be administrative costs, 5 to 7 basis points the charge levied to cover the "hurdle rate" or minimum return to equity, and roughly 8 to 10 basis points for credit risk. In our parameterization, we assume that the securitizer's transaction costs and the required return on capital amounts to 17 basis points.$^{25}$

The final parameter of interest is the cost of screening a type A mortgage applicant. We assume that the maximum cost of screening a type B is 1 percent, and then vary the costs of screening a type A from 0 to 1 percent. In 1989, the average cost of mortgage origination has been estimated to range from 1 to 2 percent. ${ }^{26}$ Total origination costs for the average mortgage in 1994 appear to be somewhat above 2 percent, but this cost involves much more than screening costs. ${ }^{27}$

\section{Comparative Statics}

We argue that increased used of automated underwriting can be modeled as a declining cost of screening type A borrowers relative to type B borrowers. The marginal cost of underwriting is the cost to the bank of collecting the private information the bank desires about risk. All mortgages extended by banks in our model are eligible to be purchased by a securitizer, but the bank can find out private information about type A mortgages easily with minimal additional investigation or use of its own mortgage credit scoring model, whereas such information is more costly for a type B mortgage (for example, the mortgage must be underwritten by a human underwriter to uncover private information). We argue that technological change is lowering the cost to the bank of developing or purchasing a mortgage credit scoring model, making it easier for the bank to identify more type A mortgage borrowers among the mortgages it is considering selling to the securitizer.

\footnotetext{
${ }^{25}$ For estimates of Fannie's and Freddie's administrative costs, see Capone (1996).

${ }^{26}$ See Passmore (1992).

${ }^{27}$ See Mortgage Bankers Association of America (1995).
} 
As outlined above, there are two cases of interest: the first where the bank securitizes all unscreened mortgages and the second where the bank keeps these mortgages. Using the parameters described above, and the equilibrium solution for the mortgage rate and the MBS rate, we find that the unconstrained screening cost cutoff in Case 2 is negative (figure 1). Recall, this cutoff must fall between zero and the maximum screening cost for a type A borrower.

The solution for Case 2 is outside this range for these parameters (as well as all other sets of parameters we investigated) because the mortgage securitizer receives only type B mortgages, and thus offers the bank an MBS rate than is below the yield on a type B mortgage, where that yield includes the bank's private liquidity premium. While securitization is a theoretical possibility in Case 2, we have yet to construct a plausible example based on realistic parameters where securitization exists in this Case. Thus, from this point, we focus only on Case $1 .^{28}$

The mortgage rate declines as the cost of screening type A borrowers declines (figure 2). The decline is about the same as the decline in screening costs, implying that the securitizer is unable to capture even some of the cost savings. (Recall, banks are perfectly competitive in our model, and thus pass any savings immediately to the borrower).

The MBS rate is almost unmoved by the decline. The securitizer is unable to lower this rate as the bank's cost of screening falls because it does not wish to induce even more screening by the bank.

In our model, banks--in the long-run--are indifferent about the mortgage rate offered, the MBS interest rate, or the proportioned screened because they earn zero profits. Instead, the capacity of the banking industry to make mortgages adjusts to reflect the movement of banks in and out of the mortgage market in response to profit incentives. The

\footnotetext{
${ }^{28}$ One possibility is that $\mathrm{k}=0$ in Case 2 . Here, the bank keeps all mortgages except those known to be type B's without screening. But when $\mathrm{k}=0$ (in either Case 1 or 2), the mortgage rate is fixed by the marginal profit condition for the bank, and not by the entry and exit of banks. Thus, bank profits cannot adjust to the parameters, and in the examples we have investigated, bank profits are always negative. We rule out cases with $\mathrm{k}=0$ because of these problems.
} 
securitizer, however, can earn positive or negative profits.

The securitizer return on equity declines as type A screening costs decline (figure 3). This decline in income reflects the heavier cherry picking by the banks. As the costs of identifying type A's falls, the banks screen more and keep more type A borrowers. The credit quality of the securitizer's portfolio falls, while the securitizer is required to use its MBS yield to offset the adverse consequences of increased adverse selection. In this example, the securitizer's desire to induce less screening by maintaining a relatively high MBS rate is successful, as the proportion of mortgages screening falls sharply (Figure 4).

As screening costs fall, the securitizer's profit eventually falls below the competitive return on capital. The securitizer would cease to securitize mortgages once screening costs of type A fell below this level. The lower costs to the bank of adversely selecting mortgages drives the securitizer out of business.

As described earlier, many mortgage purchasers or insurers-particularly Fannie Mae and Freddie Mac--are investing heavily in the technology of credit scoring. While the purpose of this investment is to determine which mortgages can be sold or insured, these investments have the spillover effect of lowering the costs of credit scoring for mortgage originators as well. We conjecture that some of the promoters of mortgage credit scoring are aware of the adverse selection problems created as this technology becomes more diffuse, but see their future as information services providers and as not mortgage securitizers or purchasers. ${ }^{29}$ In addition, some promoters may foresee that credit scoring may promote the breakdown of average cost pricing in the mortgage market, partly offsetting the adverse selection effects described here. Finally, mortgage securitizers and insurers cannot sit on the sidelines as their competition develops and promotes automated underwriting, regardless of the effects these developments have on the mortgage securitization or insurance business.

\footnotetext{
${ }^{29}$ Note that the rate of return to mortgage securitization seems to be low, even for government-sponsored enterprises (Capone, 1996). In fact, both Fannie Mae and Freddie Mac have increased the share of mortgages they hold directly relative to those they securitize because of the relatively low returns to securitization (CBO, 1996, page 7 ; OFHEO, 1996, page 39.) Fannie Mae's and Freddie Mac's substantial government advantage in funding mortgages is documented in Ambrose and Warga (1995).
} 
The social welfare implications of lower costs for bank screening are clear. Mortgage borrowers are better off because mortgage rates are lower. The securitizer's shareholders are worse off. Of course, if screening costs fall too far, securitization ceases to be possible. Our model does not attempt to describe the entry and exit decisions of current or potential securitizers.

\section{Conclusion}

Using a game-theoretic model of mortgage securitization, we illustrate the effects of a one-time decrease in the costs to a mortgage originator of finding a good mortgage credit risk. Perhaps surprisingly, we find that this decrease, which we ascribe to automated underwriting, makes mortgage securitization more difficult because adverse selection problems become more severe for the securitizer. Lower costs for underwriting encourages originators to pursue higher expected profits by screening more mortgage applicants in hopes of holding more good risks in their portfolio--applicants who would have been approved and securitized without this additional screening. Our model raises the possibility that the benefits from automated underwriting may be partly offset by the adverse selection problems incurred by the mortgage securitizer, as originators attempt to "game" the system and securitizers attempt to defend against such "gaming." However, the mortgage borrower appears to benefit from the lower costs of mortgage origination, even as the profits of the securitizer fall. 


\section{References}

Abraham, Jesse, Goetzmann, William and Wachter, Susan. September 1994.

Homogenous Groupings of Metropolitan Housing Markets. Journal of Housing Economics. 3:186-206.

Altman, Edward. November 1980, Commercial Bank Lending: Process, Credit Scoring and Costs of Errors in Lending. Journal of Finanical and Quantitative Analysis. 15:813-32.

Altman, Edward and Robert Haldeman. 1995. Corporate Credit Scoring Models: Approaches and Standards for Successful Implementation. New York University Salomon Center. Working Paper Series S-95-6.

Ambrose, Brebt W. and Arthur Warga. November 1995. Pricing Effects in Fannie Mae Agency Bonds, Journal of Real Estate Finance and Economics, 11:235-49

Avery, Robert A., Raphael Bostic, Paul S. Calem and Glenn B. Canner. July 1996. Credit Risk, Credit Scoring, and the Performance of Home Mortgages. Federal Reserve Bulletin. 82:621-648.

Berkovec, James. Glenn Canner, Stuart Gabriel, and Tim Hannan. November, 1994. Race, Redlining, and Residential Mortgage Loan Performance. Journal of Real Estate Finance and Economics. 9:263-294.

Canner, Glenn B., Wayne Passmore, and Brian J. Surette. December 1996. Distribution of Credit Risk among Providers of Mortgages to Lower-Income and Minority Home buyers. Federal Reserve Bulletin. 82:1077-1102.

Capone, Charles A. November 1996. Fannie Mae and Freddie Mac as GovernmentSponsored Enterprises: Business Strategies and Profitability. Paper presented at the Southern Economics Association annual meetings.

Chinloy, Peter. 1995. Public and Conventional Mortgages and Mortgage-Backed Securities. Journal of Housing Research, 6:173-196.

Congressional Budget Office. May, 1996. Assessing the Public Costs and Benefits of Fannie Mae and Freddie Mac. 
Cordell, Lawrence and King, Kathleen. June 1995. A Market Evaluation of the RiskBased Capital Standards for the U.S. Financial System. Journal of Banking and Finance. 19:531-62.

Cotterman, Robert F. 1994. The Effects of FHLMC's and FNMA's Mortgage Activities in: U.S. Department of Housing and Urban Development, Report to Congress on the Federal Home Loan Bank System, Vol. 2, Chapter 11.

Cotterman, Robert F. and James E. Pearce. 1996. The Effects of the Federal National Mortgage Association and the Federal Home Loan Mortgage Corporation on Conventional Fixed-Rate Mortgage Yields. In Studies on Privatizing Fannie Mae and Freddie Mac. U.S. Department of Housing and Urban Development, Office of Policy Development and Research, 97-168.

Deng, Yongheng, John Quigley and Robert Van Order. June 1996. Mortgage Default and Low Downpayment Loans: The Costs of Public Subsidy. Regional Science and Urban Economics. 26:263-85.

Fannie Mae. February 21, 1997. Mortgage Underwriting Tools-Automated Underwriting and Credit Scores, Letter to All Fannie Mae Sellers. LL01-97.

Freddie Mac. September 1996. Mortgage Underwriting: Making Mortgage Lending Simpler and Fairer for America's Families.

Goodman, John L., and Wayne Passmore. March 1992, Market Power and the Pricing of Mortgage Securitization. Finance and Economics Discussion Series, Federal Reserve Board, No. 187.

Greene, William. October 1992. A Statistical Model For Credit Scoring. New York University. Leonard N. Stern School of Business. Working Paper EC-92-29.

Guttentag, Jack M. 1992. When Will Residential Mortgage Underwriting Come of Age? Housing Policy Debate. 3:143-156.

Hendershott, Patric H. and James D. Shilling, June 1989. The Impact of the Agencies on Conventional Fixed-Rate Mortgage Yields. Journal of Real Estate Finance and Economics. 2:101-15.

Hermalin, Benjamin E. and Dwight M. Jaffee. May 1996. The Privatization of Fannie Mae and Freddie Mac: Implications for Mortgage Industry Structure," Studies on Privatizing Fannie Mae and Freddie Mac, U.S. Department of Housing and Urban Development. pp. 225-303. 
Holloway, Thomas M. and Andrew J. Jaske. May 1995. The Significance of Credit Information in Mortgage Lending Risk Assessment, paper presented at the mid-year meeting of the American Real Estate and Urban Economics Association.

Kunkel, Jim. December 1995. The Risks of Mortgage Automation. Mortgage Banking p. 47.

Lewis, Edward. 1994. An Introduction to Credit Scoring. Athena Press. San Rafael, Ca.

Linneman, Peter and Susan Wachter. Winter 1989. The Impacts of Borrowing Constraints on Homeownership. American Real Estate and Urban Economics Association Journal. 17:389-402

Nothaft, Frank E. November 1996. Lessons from the Jumbo Market. Secondary Mortgage Markets, 13:12-17.

Office of Federal Housing Enterprise Oversight (OFHEO). 1995 and 1996. Annual Report to Congress.

Passmore, Wayne. 1992. Can Retail Depositories Fund Mortgages Profitably? Journal of Housing Research. 3:305-340.

Passmore, Wayne and Roger Sparks. 1996. Putting the Squeeze on a Market for Lemons: Government-Sponsored Mortgage Securitization. Journal of Real Estate Finance and Economics. 13:27-43.

Passmore, Wayne. 1994. The Influence of Risk-Adjusted Capital Regulations on Asset Allocation by Savings and Loans. Charles A. Stone and Anne Zissu, eds., Global Risk Based Capital Regulations, New York: Richard D. Irwin Inc., vol. 2, chapter 14.

Staples, Ed. Market Moves Toward Risk-Based Pricing. November 25, 1996. Real Estate Finance Today. Page 16.

Quigley, John M. and Robert Van Order. September 1995. Explicit Tests of Contingent Claims Models of Mortgage Default. Journal of Real Estate Finance and Economics. 11:99-117.

The United States Department of the Treasury. July 11, 1996. Government Sponsorship of the Federal National Mortgage Association and the Federal Home Loan Mortgage Corporation. pp.70-75. 
Van Order, Robert. and Peter Zorn. July 1995. Income, Location, and Default: Some Implications for Community Lending. Paper presented at the Conference on Housing and Economics, Ohio State University.

Vandell, Kerry. Fall 1993. Handing Over the Keys: A Perspective on Mortgage Default Reseach. Amercian Real Estate and Urban Economics Association Journal. 21:247-63.

Vandell, Kerry. 1995. How Ruthless is Mortgage Default? A Review and Synthesis of the Evidence. Journal of Housing Research. 6:245-64.

Wolfram, Stephen. 1991. Mathematica: A System for Doing Mathematics by Computer, New York: Addison-Wesley, Second Edition. 